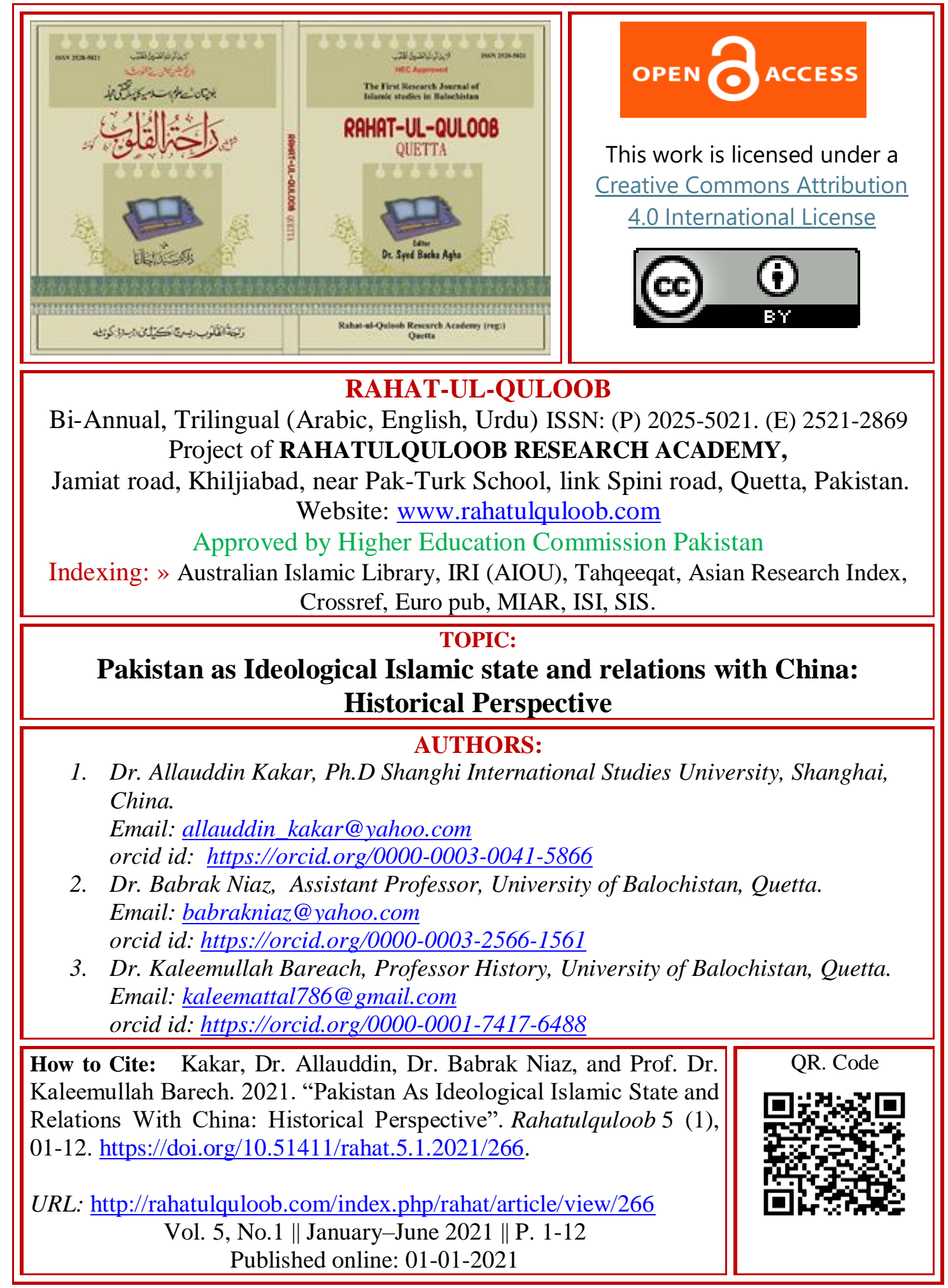




\title{
Pakistan as Ideological Islamic state and relations with China: Historical Perspective
}

\section{Abstract:}

\author{
${ }^{1}$ Allauddin Kakar, ${ }^{2}$ Babrak Niaz, ${ }^{3}$ Kaleemullah Bareach
}

The study examines China-Pakistan relations in historical perspective. Pakistan was founded on the basis of the ideology of Islam. The Islamic Republic of Pakistan has emerged as China's closest ally. Pakistan and China got independence after much bloodshed and sacrifices. Chinese adhered to the communist ideology which is opposed to capitalism, while Pakistan followed Islamic principles. Despite having two different and contradictory ideologies, China and Pakistan are not inhibited by barriers to social and cultural differences. The bilateral relations between China and Pakistan gradually grow due to strategic gains for either country overshadowing the cultural and social hindrances and ideological differences. The mutual interest made them all weather friends. Mutual diplomatic interests and pressing regional and international politics brought Islamabad and Beijing adjacent to one another to resolve their issues amicably. So, both countries started to cooperate on the diplomatic front. Pakistan extended its support on each diplomatic front and desisted from intrusive in the internal affairs of China who to is not without problems. China too was in need of a friend and good neighbor in the long struggle of international politics.

Key Words: Pakistan, China, Karakorum highway, Gawadar Port, SCO. Introduction:

Pakistan emerged as a Muslim State in August 1947. Islam is the largest and the state religion of Pakistan. China and Pakistan established diplomatic relationships on 21 May 1951. The relation are built on the strength of its successive achievements, and has becomes formidable with each passing day and year. To understand the depth of China-Pakistan friendship, the study explores the milestones reached over the years. Pakistan got independence from British India. The Muslims of India struggled for an independent state under the banner of Muslim League. Muslim League used the idea of Two-Nation for its politicking in the Raj era. The Two-Nation was expounded throughout India to the Muslims by Muslim League. It urged the Muslims that India is a motherland of two diverse nations: The Hindus and Muslims. They are dissimilar from one another in standings of culture, religion and political ideals and that they cannot live together. So, they would have a distinct political system and hence separate countries. The people of Pakistan and China are separated by natural barriers but the two countries had been connected through 'Silk Road' with one another for centuries. The Chinese used Silk Roads for trade with West Asia and Europe. Importantly, the famous Karakorum highway, located in Pakistan, was constructed in 1978 by the joint effort of China and Pakistan at an elevation of 15000 feet. It is the sign of thoughtful, trade, economic development and friendship. This route provides a window to China to reach South Asian market and oil-rich gulf countries. 
China through its economic development and non-aligned policy is leading the way in Asia. On the global front, it is an alternative source of trade and economic development and is measured reliable strategically. Other than China, different nations of Asia are struggling either for internal development or for making space in global politics. Among these nations Pakistan is not only struggling for internal development but also for its security concerns.

Pakistan and China not only share borders with one another but they also share it with India. Both China and Pakistan have fought wars with India over Tibet and Kashmir. This common for help carried together the two countries nearer to each other. Pakistan and China maintained warm relations respecting territorial integrity and common benefits non-interference in one another affairs. After the World War second, the world got alienated into the capitalist bloc and communist bloc. Each state pursued its national interest. But Pakistan and China kept respecting one another, and gradually strengthened their ties to keep up with international political order. This attitude is exemplary of friendship and trust between the countries. ${ }^{1}$

Pakistan and China both faced multi-faceted problems and matters in the foundation. The initial years were spent in addressing the initial problems and consolidating the state apparatus. The issues range from internal to external levels. The case of Pakistan was very squeaky. The partition of British India concluded in the harm of a huge number of people and bloodshed of almost two million. Around 8 million people crossed Indian land and entered in Pakistan as refugees. Pakistan had to give shelter, food and health facilities to the refugees. The economy was extremely reliant on agriculture and the state institutions had to evolve to broaden the revenue collection. The industry was nonexistent. India not only delayed Pakistan's share of financial assets and military equipment but denied some. The infant state of Pakistan had to edge a new composition that would outline the administrative and governance system of Pakistan.

\section{Evolution of china Pakistan relations}

The relations between China and Pakistan can be divided into three distinctive phases. In the initial years, the relations were neither good nor bad but normal. There were political and ideological differences that hindered their way towards friendly and proactive relations. These reservations were because of economic compulsions, security-based strategic alliances. This phase comprised the period from 1949-1961, and it can be named as a period of aversion and reluctance. The second phase that comprised the time period of 1962-1978 can be called as an era of rapprochement and trust-building. This period of rapprochement and trust started when China and India went into war over the border. The war between China and India brought China and Pakistan close to one another. Likewise, Pakistan and China amicably resolved their border issue through agreement and, Pakistan's roles in building China-USA relations. In 1971, Pakistan facilitated the China-U.S. rapprochement that essentially established diplomatic ties between the two states and reconfigured the Cold War. Consequently, the visit of President Richard Nixon' was made possible to China in 
1972. In this visit president Richard met with Mao Zedong, the Chairman of the Central Committee of the CCP (Chinese Communist Party), and Zhou Enlai, the PRC Premier. This visit was an important strategic and diplomatic approach that indicates the culmination of the Nixon administration's recommencement of harmonious relationships between China the United States after years of diplomatic isolation. 'Nixon established a secret channel to the PRC's leadership through Pakistani President Yahya Khan. In Nixon's view, Khan was an attractive intermediary since he had good relations with the leaders of both the PRC and the United States, and he also provided a means to circumvent the U.S. Department of State, which Nixon feared might oppose or publicize his initiative."

The most important is the phase of bilateral relations, which not only strengthened friendship but also made them strategic allies of all times, ranged from 1979-2019. It can be named as strategic friendship. In the wake of the international changing political scenario, the two states not only supported one another politically in international forums like the UN, etc. but also developed good economic ties and alliances. In recent years China through her 'One Belt One Road' program embarked on developing China Pakistan Economic Corridor. Through CPEC project China is investing in different sectors of Pakistan a very huge amount of $\$ 62$ billion.

\section{Formation of China-Pakistan strategic alliance}

China has a strategic interest in South Asian region due to its adjoining borders with states like Nepal, India, and Pakistan. These states also serve China's security concerns. For every state territorial integrity is one of the vital interests. Sino-Indian border issues ways back to the undefined border line between India and China by the British colonial system. China's stance is that there should be a traditional customary line whereas India believed in line of actual control which is the same as the McMohan line defined in Shimla accord $1914 .^{3}$

The rapidly changing regional environment and boarder dispute of both China and Pakistan with India compelled Pakistan and China for the formation of strategic alliances. The unease of the tension on Tibet issue escalated into a border dispute of 1962. The Soviet Union instead of supporting China took the side of India. On the other hand, the United States who was trying to contain communism assisted India and supplied her with weapons and economic aid. Pakistan was disappointed with western support in India. India was a common enemy of both China and Pakistan, so Pakistan found China as an ally with anti-Indian sentiments. Hence, due to India and China disputes, China and Pakistan came close to one another. The coming years concreted the Pak-China relations and important changes in their foreign policies. Both Pakistan and China entered into a border agreement in 1963 and started the air services. China also cooperated in the military sector to Pakistan due to which Pakistan paid heavily in the form of the arms embargo and sanctions. ${ }^{4}$ During the war of 1965 between India and Pakistan, China supported Pakistan and called India as an aggressor. War of 1971 was a great loss for Pakistan, but once again China did not 
Leave Pakistan alone in it and remained a tested friend of Pakistan.

Similarly, in 1979 when the soviet attacked Afghanistan, China condemned it as it was an open threat to Pakistan's territory and along with political support China offered Pakistan aid of 200 million US dollars. During the Kargil conflict, China tried India and Pakistan to solve their dispute with negotiations, because both of them were at the breach of MAD. At that time China was expanding its economy and Pakistan was also aware of China's economic goals with India. This did not affect Pak-China relations rather the dispute was halt and instead of full-scale war it turned off only in to limited war fortunately. ${ }^{5}$

\section{Economic partnership between China-Pakistan}

The strength of China and Pakistan's relationship can also be seen in their trade and economic partnerships because a gradual urge can be seen in it. It wasn't on a large scale during the decade of 1952-1962 which was caused due to affiliation of Pakistan with SEATO and CENTO in 1954 and 1955 respectively. Pakistan supported China during the Sino-Indian war which made a trustful relationship between both countries. Resultantly both states signed a trade agreement in 1963 followed by an improvement which was registered during the decades of the 70s, 80s, and $90 \mathrm{~s}^{6}$

The trade Graph 1.1 shows the low level of trade between two states till second quarter of 1960s. The Graph clearly depicts the nominal level of trade.

\section{Graph-1: China-Pakistan Bilateral Trade in US Million Dollars during 1952-1962}

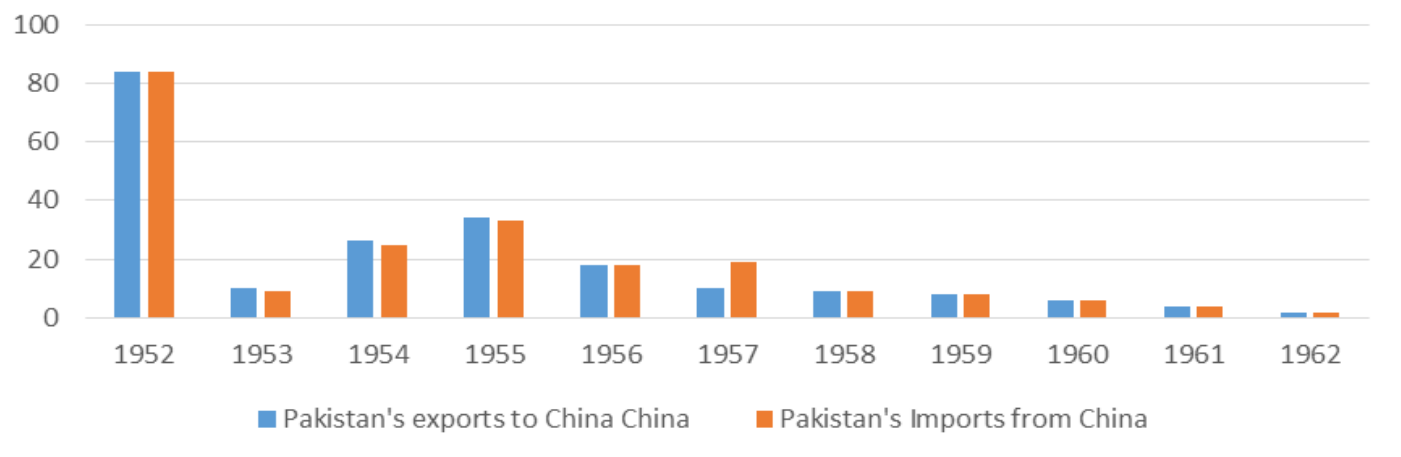

Graph-1.1: Pakistan China Bilateral Trade in \$US million Dollars [1952-1962] Source: Javaid, U., \& Jahangir, A. (2015). Pakistan-China strategic relationship: A glorious journey of 55 years. Journal of the Research Society of Pakistan, 52(1).

The trade gradually increases between the two states when the joint committee on technology and trade was formed in 1982. This can be illustrated in Graph 1.2. Graph 1.2 shows that the imports of Pakistan were greater than its exports by its trade with China. Increase imports led to the trade deficit of Pakistan in her economic relations with China. But the important aspect of this trade was that Pakistan's trade-in late 1970 to early 1990s increased as compared with its first two decades of 1950s and 70s, 1960s. Graph-1.2: Pakistan China Bilateral Trade in \$US million Dollars [1977-1990] 
Graph 2. Pakistan's Bilateral Trade with China in the US Million Dollars (1977-1990)

500

400

300

200

100

o
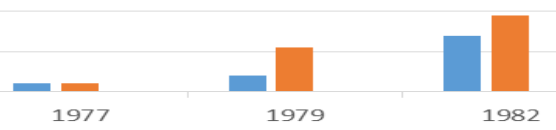

- Pakistan's Eports to China
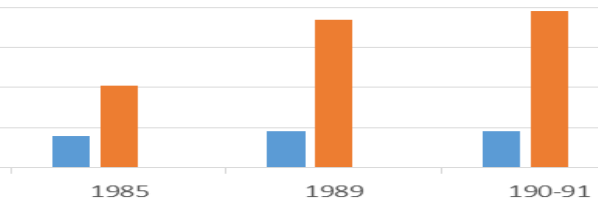

- Pakistan's Imports to China2

Source: Javaid, U., \& Jahangir, A. (2015). Pakistan-China strategic relationship: A glorious journey of 55 years. Journal of the Research Society of Pakistan, 52(1). China and Pakistan were always having a perspective of economic and trade that can never be neglected. This mutual trade relationship was not at its peak during the period of its inception like within the decade of 1952-1962, the trade was very low. Pakistan's alliances with capitalist countries or western countries were working as a hindrance to its relations with China. A new turn came after the Sino-India war in 1962 because both states, China and Pakistan, decided to trust one another which was the beginning of this long-lasting alliance. Both countries made an effort to improve their relationships in the context of trade during the decades of the 70s and 80s. It can also be seen that a joint committee on economic trade was also formulated in 1982. Imports and exports were increased by this bilateral relationship but imports of Pakistan were higher than their exports.

A decline of trade and a deficit is also recorded after 1982, which was nothing but due to the inclination of Pakistan towards America. That is why America is the biggest trading partner of Pakistan and it was the biggest cause of the declining trade. Secondly, both countries were not communicating effectively, instead, the opening of the KKH (Karakoram Highway) also could not play a positive role in trade and investment. Third, Pakistan was failing to use its sea roots and more effectively its shipping industry was not able to support import and export. Fourth, Pakistan's major export comprised cotton and its products whereas China is sufficient in producing these products in its land. These were the basic reasons that the exports could not be increased. ${ }^{7}$

\section{FTA (Free Trade Agreement)}

A free trade agreement (FTA) was also signed by both states in 2006; the first round of the agreement was to be completed in 2012. A target of $\$ 15$ million was also set to be achieved and second, was to be furnished in 2013. During this phase of 20s both countries were not having a satisfied trade. In fact exports of Pakistan were still not satisfactory. In 2018, figures show that China exported goods to the value of $\$ 11.45$ billion while Pakistan's exports to the country stood at $\$ 1.744$ billion. Under the terms of phase 2 of the FTA, it is expected that Pakistan's annual exports would now increase by $\$ 500$ million. The second phase of FTA was signed on the occasion of visit of Prime Minister Pakistan in April, 2019. The major features of the Free Trade Agreement phase 
II include Market access, protected tariff lines and safeguard measure. China is not the only country having a free trade agreement with Pakistan. Graph 1.3 and Graph 1.4 highlights the imbalance of exports and imports of Pakistan with China.

\section{Graph-1.3: Pakistan China Bilateral Trade with China before FTA in US million} Dollars 1990-2005

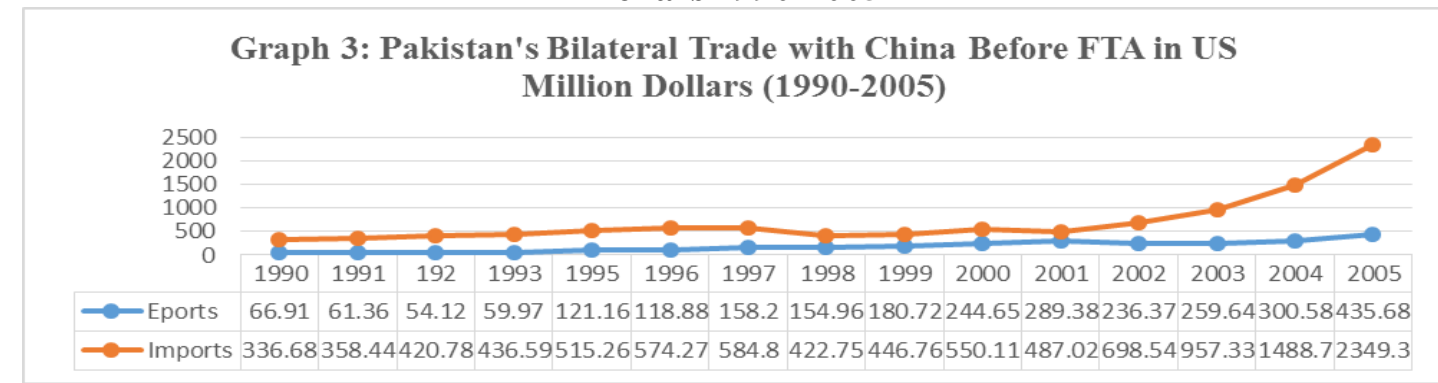

Source: Javaid, U., \& Jahangir, A. (2015). Pakistan-China strategic relationship: A glorious journey of 55 years. Journal of the Research Society of Pakistan, 52(1). Graph 1.4: Pakistan China Bilateral Trade with China After FTA in US million Dollars [2006-2014]

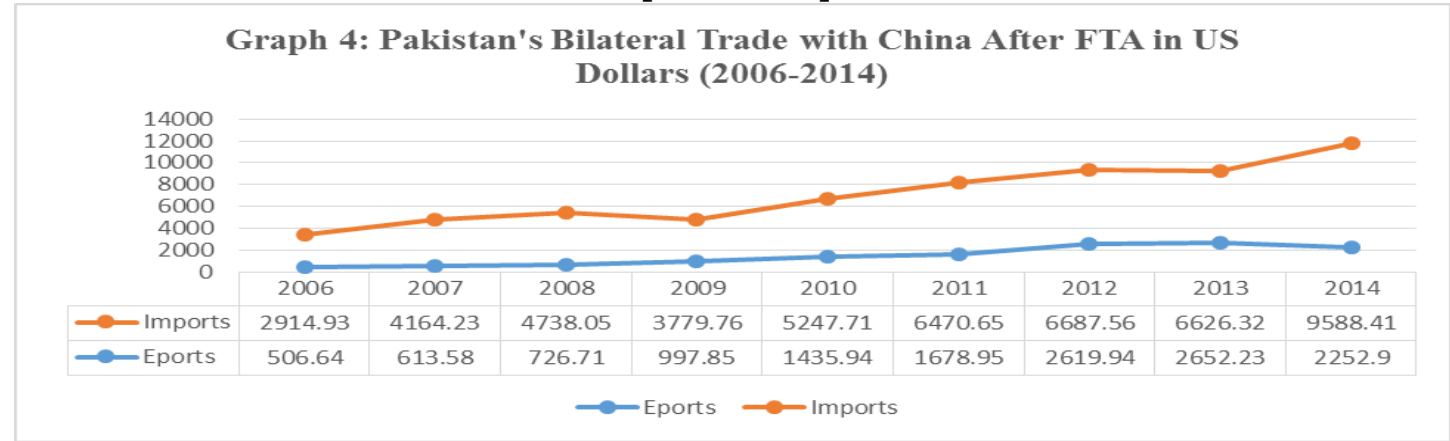

Source: "UN comtrade statistics and International trade centre" http://comtrade.un.org/ (accessed May 13, 2016)

\section{From Gilgit to Kashghar: The Karakorum highway construction}

Pakistan and China have long sensed the construction of road routes between them. For this purpose, the ever first road was built between the Kashghar province of China and the Gilgit region of Pakistan. This road link is popularly called as 'Sha-Rah-eRashm" in Pakistan. As this road passes through Karakorum mountain ranges, it is also called the Karakorum Highway (KKH). The Karakoram Highway was for the first time started in 1958 to connect China and both Pakistan. ${ }^{8}$ Its first phase was completed in 1971. There were many political and economic hindrances to impede this project. The construction of KKH highway was an adventure for both Pakistan and China. People of both sides worked hard to accomplish this project and both sides sacrificed several lives for this project as mountains of Himalayas were cut to build this road. The old silk route was revived by many tracks of this highway. In 1978, its second phase was completed. The length of this highway to link Kunjrab and Kashgar 
is 500 miles but when it is measured from capital city Islamabad, it becomes $1300 \mathrm{~km}$ long. ${ }^{9}$ Several areas of Gilgit Baltistan and China are connected by this route.

This route made both countries to interact closely and it made the approach to other countries possible. It was also the first step to open a new direction of the economic corridor. Tourism was also increased after this route and revenue were also generated by this field. Trade between Xingjian and Pakistan's people were also increased due to this project. This road also opened opportunities for tourists to visit scenic valleys and tourist spots. This road introduced resourceful northern Pakistan to the world.

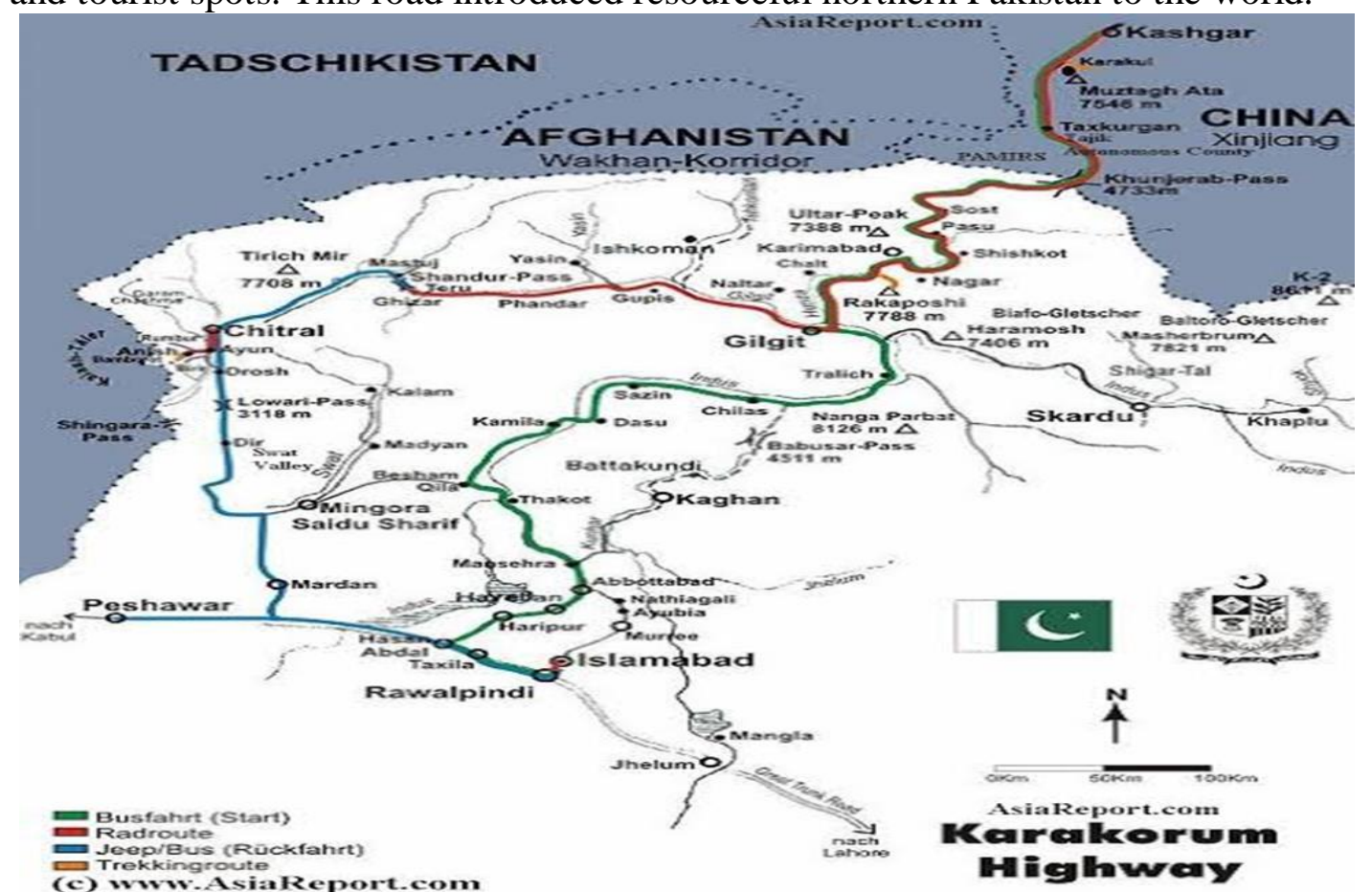

Source:Google,https://www.google.com/search?q=china+pakistan+karakoram+highway+map \&rlz=1C1GGRV_enPK769PK769\&oq=china+pakistan+karakoram+highway+map\&aqs=chr ome..69i57j0.22217j0j8\&sourceid=chrome\&ie=UTF-8

The Karakorum Highway was built to increase trade activities and develop public to public interactions between the two countries. China has its long-standing aspiration to open different avenues and channels of trades with all states of the world through her initiative of OBOR. In order to fulfill this dream, Pakistan's Gawadar Port was a good link to access the Gulf States. Developing Gawadar port is essential for both Pakistan and China's economic and strategic needs respectively. The idea existed for quite long as since the 1960s but the eventual ceremonial inauguration happened in Musharaf era.

\section{Gawadar port}

It was instigated in 2002 by the inauguration of Gawadar Port by both China and Pakistan. It was indeed a new chapter in the history of their friendship. In fact, oil and mineral resources are very enriching in Baluchistan, the province of Pakistan on one 
hand, and Geographically, Gawadar is attached to the Arabian Sea and it has a route to connect with landlocked countries of Central Asia and Afghanistan on the other hand. China can also get easy access to the strait of Hurmuz, Persian Gulf, Arabian Sea, and Central Asian states. It is to be completed in phases. Its first phase has been completed in 2005. In this project, China has spent $\$ 198$ million out of 1.16 billion dollars. ${ }^{10}$

Both countries constructed a highway which was named as Makran Coastal Highway. This highway is having a length of $700 \mathrm{~km}$. Its second phase has also been completed which connects Karachi with Gawadar and the Arabian Sea. The whole second phase was financed by China. This measure of both countries will provide jobs to unemployed people and their economy will also grow. China financed 200 million dollars to complete this project. Railway tracks are also part of this project which will be furnished with the cost of $\$ 1.25$ billion. Road of this mega project is to link China with the port of Gawadar. This investment is a need for Pakistan as her economy is categorically in recession. In order to gain economic boost and to evolve and develop infrastructure, the aim of CPEC is to sustain economic stability in the competitive region.

\section{Sino-Pak defense and military relations}

A new trust was built between both states after 1963 and they became a trusted ally. Pakistan could not get any financial or military support from western block during its wars and crucial time. At that time Pakistan was in a dire need of a friend in this region because America did not extend any support towards Pakistan during the 1965 war. China came to the front and supported Pakistan during the war on Military as well as financial grounds. China made Pakistan able to develop its own weapons. It provided 40 million to Pakistan in 1969. All these efforts of both countries made their relations more vide ranging because the regional balance of the power was the requirement of the time. ${ }^{11}$

China's services to Pakistan can be seen in every fields of Pakistan defense like air force, navy and army. It helped Pakistan to build heavy mechanical complex, aeronautical complex and ordinance factories. A wide range of missiles and aircraft were also made with mutual cooperation of both states in 1999. In 2003, assistance was also provided to Pakistan to make JF-17. An amount of 600 million dollars was also provided to Pakistan to advance its naval capacities. ${ }^{12} \mathrm{~K}-8$ was also constructed to replace the $\mathrm{T}-37$ series.

\section{The rise of SCO and Pakistan}

Similarly, Shanghai Cooperation Organization has been playing an important role in the strategic development of Pakistan. Shanghai Cooperation Organization is an international as well as regional organization created for the stability and security of the central Asia in 2001. This organization was extended from Shanghai five. China, Russia, Uzbekistan, Kazakhstan, and Kyrgyzstan are its permanent members. Pakistan, Iran, Afghanistan, and Mongolia are its observer states or having the status of observer states. Pakistan has also expressed to become its permanent member in 2006. Russia was in favor of Pakistan to become a permanent member in 2011, meanwhile, 
China also endorsed the Russian point of view regarding the matter. An effort was also made by China to convince other member states in $2014 .^{13}$

The main agenda of SCO is to halt separatism, extremism, and terrorism. These are the main issues of this region that is why the main manifesto of the organization moves around these issues. Pakistan is facing all these problems because of its location because it is situated in West Asia, central Asia and East Asia. Pakistan is directly concerned with these issues. The participation of Pakistan will help it maintain good relationships with all other regional states which will enhance the possibility of its mutual cooperation to resolve all these issues. Due to all such importance of Pakistan now it is a permanent member of the SCO. Pakistan became the permanent member of the SCO in 2016 by signing memorandum. ${ }^{14}$

India has also become a permanent member of it. Pakistan is providing the economic potential to the region because it can work as a gateway to the Central Asian states.

\section{Pakistan support to China at the United Nations}

The UN general assembly passed a resolution 498 during the year 1951 according to which UN accepted China as an aggressor for leading war in Korea. ${ }^{15}$ Pakistan supported China in United Nations to occupy a seat by replacing Kuomintang delegation. As an outcome of which the UN imposed a restriction on the export of some specifics goods to the areas under the control of China. Pakistan refused to vote against China by expressing a goodwill gesture towards China. In response to Pakistani favor China showed ambiguity over Kashmir issue even during the full moon days of Sino Indian relations.

Till 1959 Pakistan supported Taiwan in the UN for seeking authorized status. This action of Pakistan had weakened Sino-Pak relations. Later on in 1961 Pakistan improved the Sino-Pakistan relations by subsidiary China, at UN general assembly's forum and voted for China for its legitimate status which later in 1971 China was acknowledged in the UN. ${ }^{16}$

\section{Pakistan's partnership with the West}

During the cold war, the world system was bipolar. It is very tough for the hegemonic power to maintain the status quo while beating a competitor. USA's policy during the cold war was to raise its alliances through military and economic aid and to counter the China and USSR's Communist expansion. In fact, small states often suffer from big powers rivalry. Hence, for Pakistan, its policies are Indo centric. And India is a threat at its doorstep, especially when Pakistan was a newly born state. It was problematic for her to assimilate herself militarily and economically in contradiction of the bigger opponent India. United States took Pakistan as a means to use it in contradiction of the Soviet expansion while Pakistan thought that the US would support her in securing its territory and arguments over the Kashmir matter, Indus water treaty and the allocation of economic assets. For that Pakistan arrived into the defense deals with the US namely SEATO (South East Asian Treaty Organization) and the CENTO (Central Treaty Organization) known as the Baghdad Pact in 1954 and 1955 respectively. 
Taking into account Pakistan's partition in SEATO and CENTO, it could have a direct influence on Pakistan-China relations. Nevertheless, Pakistan has expressed her views to maintain friendly relations with China before joining the United States alliances but it created an atmosphere of cold ties between China and Pakistan. Chinese perspective was, on joining the American block, she would use Pakistan's territory as a war base and it could undermine Pakistan's security leading to create unrest in the South Asian region. SEATO is a tool which America is using to contain China and thus creating tensions in Indo-China, Far East and neighboring states. ${ }^{17}$

\section{Sino-Soviet split and China-Pakistan relations}

Pakistan's relations with soviets have not been very friendly since Pakistan's independence, while China shared the ideological relations with the USSR (Union of Socialist Republic of Soviet Republic) at independence time. Sighted that Pakistan is not interested in following the USSR, Soviet-supported India on Kashmir. It was now clear to Moscow that Pakistan's first priority is to secure herself from India rather take any aggressive action against them still due to strategic position of Pakistan from the Persian Gulf and northern areas to soviet and China it tried to maintain trade relations with Pakistan. ${ }^{18}$

Chinese relations with USSR remain friendly and followed cooperation from 19491955. It was the period when soviet provided China with massive economic, military and technical aid and assistance. China signed a treaty of friendship alliances and mutual assistance in February 1950. Soviets also supported the membership of China in the UN, and also in the Korean War. The alterations began to emerge after 1955 between the China and Soviet Union. China had realized that Soviet wanted to impose its ideas on them, and after the Cultural Revolution in China, it started to tilt towards the free trade structure and grasped that it is essential for China to come out of isolation and develop relations with neighbor states and the west. The Soviet-Sino split ongoing emerging in the 1960s and Soviet criticized China for the great leap forward, the relations were more crucial in 1962 and 1963 following ideological differences and boarder confrontations. This controversial political orientation of Soviet was a threat to Chinese vital interest and goals. ${ }^{19}$

Relations between the China and Soviet Union was tense, the India relations with Pakistan, brought both the countries China and Pakistan much closer to one another for mutual support. It thus paved the way to bring China closer to the USA with the help of Pakistan. This doesn't end here, China took Pakistani help to develop and maintain warm relations with Gulf countries. China needs a reliable friend in South Asia because at that time it was indulged in territorial dispute with India as well as Soviet were supporting India against Pakistan and China and at that time both Pakistan and China were a supportive shield for one another.

\section{Conclusion}

Thus, since the establishment of their diplomatic ties China and Pakistan has been enjoying an all-weather friendship. China has provided economic, military and 
diplomatic support to Pakistan, and considers Pakistan a close strategic ally. China is a state that has to give the world a contemporary system where there are no permanent friends or enemies. No doubt the national interests are always preferred on national relations. In the present world, most of the developed and developing states make their relations and cooperate with other states for the sake of own interests. No doubt, China is a close friend of Pakistan and supported Pakistan at every stage but even then where national interests come, there are at times when divergence is observed between Pakistan and China's interests. Both the states always have to prefer their national interests, in the same way, these interests that compel China to go for greater trade and economic partnership with India. The most important determinant of foreign policies and global politics is national interest so analysts always keep it in mind that China-Pakistan friendship is deeper than deep seas and higher than mountains but it is subservient of national interests. China will always have a preference for her own interests in case of any divergence between Pakistan and China national interests.

\section{References:}

${ }^{1}$ Vandewalle, L. (2015). In-depth analysis Pakistan and China:'Iron brothers' forever? European Union Policy Department, Directorate General for External Policies, 18.

${ }^{2}$ Manju J, (1997). The United States and China: Towards A Rapprochement, Indian Journal of Asian Affairs, Vol. 10, No. 2. pp. 43-68.

3 Jiali, M. (2012). China-South Asia Strategic Engagements-1: China's Strategic-security Interests in South Asia: Institute of South Asian Studies.

${ }^{4}$ Hussain, N. (2012). Pak-Russia Relations: Lost Opportunities and Future Options. Journal of Political Studies, 19(1).

${ }^{5}$ Jabeen, M. (2012). Developments in Pak-China Strategic Alliances.

${ }^{6}$ Rahman, F.-u. (2011). Pakistan-China trade and investment relations. Paper presented at the seminar on Pakistan-China Relations-2011: Year of Friendship, Islamabad.

7 Akhtar, S. (2014). Sino-Pakistani Relations: An Assessment. The Institute of Strategic Studies, http://www. issi. Org. pk/old-site/ss_Detail.php.

8 Munir, M. (2018). Pakistan-China Strategic Interdependence: Post-9/11 Imperatives. Strategic Studies, 38(2).

${ }^{9}$ Abid

10 Anwar, Z. (2010). Gwadar deep sea port's emergence as regional trade and transportation hub: Prospects and Problems. Journal of Political Studies, 17(2), 97.

11 Shah, H., \& Choudhry, A. (2013). Pak-China Diplomatic and Military Relations: An Analysis. Berkeley Journal of Social Science, 3.

12 Zeb, R. (2012). Pakistan-China relations: where they go from here? Revista UNISCI (29), 45-58.

${ }^{13}$ Xia, Y.(2014) The People's Republic of China. Ashgate Research Companion to the Korean War,72.

${ }^{14}$ Zeb, R. (2012). Pakistan-China relations: where they go from here? Revista UNISCI (29), 45-58.

${ }^{15}$ Xia,Y.(2014) The People's Republic of China. Ashgate Research Companion to the Korean War, 61.

16 Jabeen, M. (2012). Developments in Pak-China Strategic Alliances.

${ }^{17}$ Syed, A. H. (1974). China \& Pakistan: diplomacy of an entente cordiale: Uni of Massachusetts Press.

18 Hussain, N. (2012). Pak-Russia Relations: Lost Opportunities and Future Options. Journal of Political Studies, 19(1).

${ }^{19} \mathrm{Li}$, M. (2011). Ideological dilemma: Mao's China and the Sino-Soviet split, 1962-63. Cold War History, 11(3), 387-419. 